\title{
Shares of housework between mothers, fathers and young people: routine and non-routine housework, doing housework for oneself and others
}

\author{
Lyn Craig and Abigail Powell
}

\begin{abstract}
We use data from the most recent Australian Bureau of Statistics (ABS) Time Use Survey to investigate shares of domestic work along two dimensions; routine and non-routine activities, and housework done for the whole household versus housework done for oneself only. We argue that the latter is an underutilised marker of responsibility for household management and serving others. Exploiting data from matched household members, we examine relative shares of fathers and mothers, and also of co-resident young people aged 15-34 (416 households), to include inputs from the younger generation as well as the parental couple. Mothers do the greatest share of routine housework and housework for others; parents are relatively equal in the shares of non-routine housework and housework done for themselves only. Young people take on a minimal share of total household work, particularly tasks done for others in the family.
\end{abstract}

\section{INTRODUCTION}

Gender differences in the division of domestic labour are well-established (Bianchi, Robinson and Milkie 2006; Sayer 2005). Although on average men's housework has gone up over time, it has done so only slightly, and women continue to perform the greatest share (Bianchi and Milkie 2010; Cooke and Baxter 2010). The persistent discrepancy has implications for gender equity in the paid workforce as well as in the home (Bergmann 2005; Gornick and Meyers 2003; Lachance-Grzela and Bouchard 2010). The household division of labour is one of the "most obdurate features of our current gender system" (Ridgeway and Correll 2004: 512). A component of gendered housework patterns is that men exercise more choice than women over which tasks to perform and when to perform them (McMahon 1999). Thus there are differences are not only in amount of time spent, but also in what tasks are performed.

Research has shown task specialisation by gender, with regular 'routine' housework encompassing cooking, grocery shopping, cleaning and laundry, typically the province of women, while more time-flexible, sporadic tasks such as outdoor work and maintenance are more likely to be done by men (Baxter 2002; Bianchi and Milkie 2010; Hook 2010). The routine, regular tasks are regarded as most onerous and time-constraining (Dempsey 2001; McMahon 1999; Sullivan 1997). Although men's participation in some routine housework, notably cooking, has risen in recent years, task separation persists (Craig, Powell and Brown 2015; Sayer 2005). Furthermore, women are typically assigned the role of domestic manager, with overall responsibility for the running of the household. In most families, mothers are where 'the buck stops' domestically. They are usually more responsible for organization, maintaining harmony, managing relationships, and performing the emotion work necessary to family life (Coltrane 2000; Mattingly and Sayer 2006; Strazdins and Broom 2004).

Among other things, this suggests that much of women's housework is likely to be performed as a service to others, for the benefit of the whole household, while more of men's housework is likely to be done for themselves only and involve little service to others or planning on 
their behalf. This is an important distinction. Many women describe taking responsibility for organization as the most onerous aspect of domestic labour (Coltrane 2000; Deutsch 2000). It is much easier to 'help out', and do tasks only when and if requested (Sullivan 1997). We argue it is similarly easier to look after oneself only, rather than to think about, plan for, and meet others' needs.

Of course, men doing housework for themselves may relieve their wives of having to do some chores for them. Nonetheless it is unlikely to ameliorate women's subjective experience of lacking domestic support. This widely felt lack of support translates to a social phenomenon that has been described as 'the wife drought' (Crabb 2015). The 'reversed-role family' has been long-heralded (Russell 1987), but it is still the case that in heterosexual couples most men are net recipients of domestic servicing, while women rarely are (Crabb 2015; Fineman 2004; Folbre 2001). The implication is that few women enjoy the luxury of delegating much responsibility for domestic organization and service to others in their family. Previous research analysing housework has not directly investigated markers of differential responsibility for others. We remedy this gap, exploiting the unusual detail of our data source, the Australian Bureau of Statistics Time Use Survey 2006, to differentiate not only between routine and non-routine tasks as is standard in the literature, but also between housework performed for the household, or for oneself only.

We also advance the literature by offering a more inclusive picture of contributors to total household work than prior research. Although scholars increasingly argue that work-family issues should be approached from a household, rather than an individual, perspective (Bianchi and Milkie 2010; Cooke and Baxter 2010), "most studies of 'household' divisions are actually reporting 'conjugal' distribution of labour, since they discuss only the adult partners' participation" (Punch 2001: 803). Yet research conceptualising the domestic workload as the combined inputs of couples overlooks that family units include others who could contribute, including teenagers and young adults. In this paper we are interested in the extent to which young people share the burden of household work with their parents. The presence of young children in a household creates a demand for parental housework time, which lessens as they grow (Craig and Bittman 2008; Ironmonger 2004). When children are young and learning life skills they are likely to do little housework, especially independently (Bonke 2010; Miller 2005). Both children and teenagers have objectively low domestic time inputs (Hilbrecht, Zuzanek and Mannell 2008; Wight et al. 2009), but those over the age of 20 do slightly more (Craig, Powell and Brown 2015). The social categories of 'parent' and 'child' may carry expectation about domestic roles analogously to the categories 'man' and 'woman', such that young people and their parents adhere to normative patterns whereby net domestic services flow downwards from the older to the younger generation. If so, we could expect that young people would perform a greater share of the housework for themselves than of work done for the whole household.

\section{Research focus}

This paper uses time diary data from matched family members to examine the gender and generational division of domestic labour in households in which children aged 15 and over live together with their parents, distinguishing between routine and non-routine tasks, and between housework done for oneself or for others. We advance research on gender divisions of labour in three ways. First, for whom housework is done is an underutilised marker of responsibility for household management and service. Second, we focus not on amount of 
time spent, but on how housework is actually shared between household members, including co-resident young people. The vast majority of previous investigation into unpaid work concentrates on couples (Punch 2001), and relies on either time diary records of individual unrelated men and women (see for example Hook 2006; Sayer, Bianchi and Robinson 2004) or upon one partner's estimation, which may be subject to reporting bias (see for example Fuwa 2004; Geist 2005). Our analyses improve on these approaches as they are based on independent records of the actual time allocation of fathers, mothers and young people in the same household, from which we derive their relative shares.

\section{DATA AND METHOD}

We analyse data from the Australian Bureau of Statistics (ABS) 2006 Time Use Survey (TUS), a nationally representative sample of Australian households. All individuals aged 15 years and over in sampled households are required to provide time use information.

Respondents record their primary activity, any simultaneous (secondary) activity, where they are, who they are with and (significantly for this study) who they do the activity for, to a detail level of five minute intervals, over two consecutive diary days.

We select households in which two heterosexual parents co-reside with young people aged $15-34$, and at least one household member has reported doing domestic labour on the diary day. Because we are interested in gender shares, single parent households are excluded, as are households with three generations or more than one family unit. This means young adults with their own children are excluded. Some households include children under 15 - these are younger siblings of young adults living with parents. However, we are unable to examine the domestic contribution of children under 15 since they are not required to complete the time use survey. We arrange the data such that both parents' and co-resident young peoples' information was combined as one household record for each diary day. Our final sample is 416 households (813 diary days), comprised of 832 parents and 591 15-34 years olds. Information about the sample is detailed in Table 1.

[Table 1]

\section{Dependent variables}

Our interest is in domestic work (ABS 2006 TUS codes 400-499) which includes food preparation (e.g. cooking, clean-up, setting the table); laundry and cleaning (e.g. washing, ironing, sorting clothes, wet and dry housework); outdoor work (e.g. gardening, animal care, cleaning grounds, pool care); household maintenance (e.g. home improvements, making furniture and furnishings, car care); household management (e.g. paperwork, bills and budgeting, recycling and disposing of rubbish) and communication and travel associated with domestic work and purchasing consumer goods (ABS 2006 TUS code 611 purchasing groceries, food etc.).

Our focus is not the amount of time respondents spend in these activities, but rather how the total household work is divided between household members in relative terms. Thus our dependent variables are shares of household work. To calculate shares we first computed total minutes per day spent in domestic work by mothers, fathers and co-resident young people combined. The sum of all respondents' contribution makes up total household 
domestic work; the total combined time they spend on domestic work as a main activity. Second we disaggregated total domestic work along two dimensions:

1. Activity type:

a. Routine tasks: the sum of food preparation, laundry and cleaning and grocery shopping, and

b. Non-routine tasks: the sum of outdoor work, household maintenance, and household management.

2. For whom the activity is done:

a. exclusively for oneself

b. for the household, including activities done for both others in the household and oneself. (For example, if a person has cooked dinner for the whole family, including themselves, this has been coded as done for the household.)

To calculate relative shares we divided each of these measures by mothers, fathers and young peoples' combined total domestic work, creating two sets of six ratio measures that sum to one. Together the first six measures show the ratio (proportion) of a household's total routine domestic work to a household's total non-routine domestic work, as well as mothers, fathers and young peoples' shares of routine and non-routine domestic work relative to each other. Together the second six measures show the ratio (proportion) of a household's domestic work performed for others to a household's domestic work performed for oneself, as well as mothers', fathers' and young peoples' shares relative to each other. Table 2 shows means for each set of ratio measures for all households that reported performing any domestic work on the diary day, and the mean minutes per day spent in each aspect of domestic work by mothers, fathers and young people.

[Table 2]

\section{Analysis plan}

We estimate a series of OLS regression models to examine relative shares of routine and nonroutine housework and housework performed for oneself or for others. As a preliminary step we directly tested gender and generation gaps by running models on pooled observations of mothers and fathers and young people. These are not shown, but we report results where relevant in the text, and full tables are available upon request. In main analyses we estimate models for mothers, fathers and young people separately.

Our key independent variable is parents' employment configuration, which the literature suggests would be related to the way they share domestic labour between themselves (Crompton, Brockmann and Lyonette 2005; Gornick and Meyers 2004). Employment is captured in dummy variables (dual full-time earner (omitted)/father full-time, mother parttime/male breadwinner (father full-time, mother not employed)/father not full-time). The variables simultaneously capture both spouses' time availability and tap an indirect indicator of their relative contribution to household income. With the possible exception of 'father not full time', they also arguably give an indirect indicator of parents' gender ideology. Male 
breadwinner (MBW) households are viewed as most traditional, and dual full-time earner (DFT) households most progressive (Hook 2010).

We control for household characteristics that previous research has found to be related to housework and/or to the presence of young people in the family home. We include a measure of the socio-economic status (SES) of the area in which households are situated (lowest 60\%(omitted)/highest 40\%), because class is associated with domestic work (Baxter 2002) and children's co-residence at older ages (Mahaffy 2004). We prefer this measure to household income, because older parents may be retired or semi-retired and thus have low current income that does not reflect their accumulated wealth. We enter whether the household usually speaks a language other than English at home, as an indicator of being from a minority ethnic group, non-English speaking household (yes/no (omitted)) - because these households have been found to have more traditional patterns of household time allocation (Craig, Powell and Brown 2015). We control the number of co-resident young people, because more of them are likely to perform more housework in total, but perhaps to do proportionately less each. We enter a dummy variable indicating whether there are children under 15 in the household (no omitted) as they are likely to create more housework and be associated with more traditional gender divisions of labour between parents (Craig and Mullan 2010; Dribe and Stanfors 2009). Due to the sample restrictions described above, these will be siblings, not off-spring, of the young people. Finally, we control for absolute total hours households spent in housework. Outcome variables are thus net of time differences in overall amount of housework. This means the influence of differing standards or demand relating to factors such as dwelling size are to some extent controlled, and we can focus on relative shares and housework composition.

The reference group across the main models is a mother/father/young person in a household in which both parents work full-time, the household contains one young person with no sibling under 15 years, is in the lowest $60 \%$ of SES and is English speaking. For space reasons, we do not discuss the results of the control variables in the text. Analyses accounted for clustering of persons within households and were weighted to ensure an equal distribution of days of the week.

\section{RESULTS}

Table 3 shows OLS results for the proportion of routine and non-routine domestic labour performed by mothers, fathers and young people, respectively. Table 4 shows OLS results for the proportion of domestic labour performed 'for household' and 'for oneself' by mothers, fathers and young people, respectively. In each table, intercepts for mothers, fathers and young people sum across, adding up to 100 per cent of household domestic labour performed by all parties. We thus have an overview of households' total domestic work composition by routine vs non-routine activity (Table 3 ) and by for whom the housework was done (Table 4). We also have each person's proportional contribution to the household total that is comprised of each dimension of domestic labour. This means that each coefficient can not only be interpreted in relation to the intercept in each model, but also that coefficients across models can be read together, because an increase in one implies a decrease in others.

\section{[Table 3]}

[Table 4] 
Reading across intercepts in the top row of Table 3 shows that, in reference category households, $58 \%$ of total household domestic labour was routine activities performed by mothers, $19 \%$ was routine activities performed by fathers and $6 \%$ was routine activities performed by young people. This means that $83 \%$ of the total domestic work in these households was comprised of routine domestic labour activities, with mothers contributing nearly three times as much of this type of housework as fathers, and nine times as much as young people. Seventeen per cent of these households' total domestic labour was comprised of non-routine activities, constituted by mothers and fathers each performing $8 \%$, and young people $1 \%$, of the household total domestic work.

Reading across intercepts in the top row of Table 4 shows that in reference category households, of the total domestic labour performed by all parties, $49 \%$ was performed for the household by mothers, $13 \%$ was performed for the household by fathers, and $2 \%$ was performed for the household by young people. This indicates that $64 \%$ of total housework was done for the household, rather than for oneself only. Mothers were estimated to contribute over three times as much of the housework done for the household as did fathers, and 25 times as much as young people. Mothers, fathers and young people in the reference category were estimated to perform $18 \%, 14 \%$ and $5 \%$ respectively of total household work as housework that was done for oneself only. So $37 \%$ of the total domestic labour these households performed was done for oneself only, rather than for the whole household. On this measure, there was only a four percentage point difference between men and women (which the preliminary pooled models showed was not statistically significant), and parents averaged three to four times as much of this type of housework as young people.

These results illustrate gender and generational inequity in total housework shares. Overall on each dimension of housework, reference-category mothers, fathers and young people are estimated to do $67 \%, 27 \%$ and $7 \%$ of the total respectively. As expected, our analyses showed that share differences were widest in routine housework; that is, in tasks that are more laborious and must be done regularly (Sullivan 1997), and in housework done for the household, rather than oneself only.

We found parental employment configuration was relevant to how housework was shared between mothers and fathers. Compared to dual fulltime earner (DFT) households, in households in which the father worked full-time and the mother part-time (FTPT), men were estimated to do four percentage points less of the routine housework. There were positive coefficients for part-time working mothers' routine and non-routine housework, although, probably because the share displacement was spread across both activity types, they did not reach statistical significance. In MBW households, women were estimated to do 11 percentage points more of the routine housework than their counterparts in dual earner households. This higher share was matched by a lower share of routine (six percentage points) and non-routine (five percentage points) domestic work by fathers. There were no share adjustments by young people in relation to parents' employment. We also found evidence that fathers who did not work full-time (i.e. were employed part-time or were out of the workforce) took on a greater share of non-routine housework (six points more). There were also indications that in these households fathers did a higher share and mothers a lower share of the routine housework (five percentage points more and six percentage points less, respectively), although this was only marginally statistically significant. 
With regard to housework done for the household rather than oneself, results again suggest parents in male breadwinner (MBW) households traded off shares with each other (mothers were estimated to do 10 percentage points more than in dual full-time earner households, and fathers 11 percentage points less). Fathers not employed full-time (FNFT) were estimated to do a larger share of the housework done for oneself (eight percentage points). In this case, we observed negative coefficients for both mothers and young people's share of the housework done for the household (seven and two percentage points, respectively). This implies that non-fulltime working fathers' higher share of housework for themselves replaces the relative share of both mothers and young people's housework for others, although we caution that significance was only at the 10 percent level. Results for parents' employment configuration (all other variables held at the reference category) are illustrated in Figure 1.

\section{[Figure 1]}

\section{DISCUSSION AND CONCLUSION}

We used high-quality Australian time-diary data from matched household members to investigate shares of domestic work along two dimensions: routine vs non-routine household tasks, and domestic work done for the household versus domestic work done for oneself only. The latter distinction offers a window into an aspect of domestic responsibility that many women find particularly onerous: managing and servicing others (Coltrane 2000; Deutsch 2000; Sullivan 1997), but which has not been the focus of prior time use studies. We also offered a new inclusive picture of contributors to total household work, by looking at households in which young people aged 15-34 are co-resident with their parents. This improved on studies of 'household' divisions that discuss only adult couples' participation (Punch 2001: 803).

Most obviously, and confirming a very large body of prior research, was that mothers' overall share of domestic labour far outweighed that of other household members. Mothers contributed the bulk of the routine housework and the household labour that was done for the household. The results also starkly highlighted that parents remain the primary providers of household labour, including beyond their children's teenage years. Young people's share of the total domestic work in co-resident households was very low. On the 'for whom' dimension, young people had slightly higher estimates for housework for oneself than housework done for the household. This implies that they relieve parents of some relative responsibility but more by looking after themselves than others.

The patterns identified may be driven by both generations. Parents may be reluctant to alter their shares of domestic responsibility because they feel accountable for behaving consistently with prevalent cultural beliefs about gender roles (Berk 1985; Brines 1994; Greenstein 2000; Ridgeway and Correll 2004; West and Zimmerman 2009), because of preferences internalized over time, or due to taken-for-granted assumptions about the way to behave (England 2010; England 2011). Assumptions about housework responsibility are also likely to be relevant to the social categories 'parent' and 'child', such that domestic services flow strongly down the generations. It may be particularly difficult for mothers, who are predominantly the primary carers, to adjust from doing everything for young children to expecting them to take over some net responsibility for domestic tasks as they grow (Kloep and Hendry 2010). And of course young people themselves have agency; they participate in household labour through everyday interaction, forming part of the social structure offering 
opportunities to undo or to perpetuate established patterns, again analogous to the way gender behaviours are actively constructed (Connell 2009; Ridgeway and Correll 2004; West and Zimmerman 2009). It may be difficult to increase young people's contribution to the household chores as they mature if they prefer to make minimal contributions.

Parents' employment configuration was relevant to how housework was shared between mothers and fathers, as expected. Our measures showed that this was particularly so for routine housework and housework performed on behalf of others. Parents were estimated to have significantly more unequal shares on these measures in MBW than in DFT households, consistent with arguments they have a more traditional gender ideology (Hook 2010) or due to limited male time availability in MBW households. Fathers not employed full-time were estimated to do a larger share of the household work, but interestingly it was for themselves, rather than for others. This implies that even if they have more time available for housework, men will not necessarily take over any relative responsibility for service to others. We also found that parents' employment had little association with young people's contribution, underlining that they are quite marginal to household production.

This study is subject to a number of limitations. The data are cross-sectional and our analyses identify correlations only, not causal effects. Selection effects may affect our findings, particularly in relation to young people. Those who live at home are arguably more dependent on their parents than those who have left the family, either financially or emotionally, and as such may be uninclined to take on domestic responsibility (Mahaffy 2004). Households in which young adults co-reside with parents may be more conservative (Mitchell 2006). We are also limited by the fact that we cannot include the household labour of children aged under 15. Furthermore, our data cannot distinguish between young people that have never left the family home and those that have left and returned. The latter are thought to be increasing in number in both the USA and Australia (de Vaus 2004; Mitchell 2004), and we may expect them to be more independent, depending on the reasons for their return. Should the data become available, future research using fixed effects modelling with longitudinal data could better account for potential selection effects and unobserved heterogeneity. Since domestic labour patterns differ cross nationally due to varying workplace structures, social policies and cultural norms (Fuwa 2004; Geist 2005; Gornick and Meyers 2003; Hook 2010), future research could also examine whether these findings pertain in other countries.

\section{REFERENCES}

Baxter, Janeen. 2002. "Patterns of Change and Stability in the Gender Division of Household Labour in Australia, 1996-1997." Journal of Sociology 38(4):399-424.

Bergmann, Barbara. 2005. The Economic Emergence of Women Second Edition. New York: Palgrave MacMillan.

Berk, Sarah Fenstermaker. 1985. The Gender Factory: The Apportionment of Work in American Households. New York: Plenum.

Bianchi, Suzanne, and Melissa Milkie. 2010. "Work and Family Research in the First Decade of the 21st Century." Journal of Marriage and Family 72(3 ):705-25. 
Bianchi, Suzanne, John Robinson, and Melissa Milkie. 2006. Changing Rhythms of American Family Life. New York: Russell Sage.

Bonke, Jens. 2010. "Children's housework - Are girls more active than boys?" electronic International Journal of Time Use Research 7(1):1-16.

Brines, Julie. 1994. "Economic Dependency, Gender and the Division of Labour at Home." American Journal of Sociology 100(3):652-88.

Coltrane, Scott. 2000. "Research on Household Labor: Modeling and Measuring the Social Embeddedness of Routine Family Work." Journal of Marriage and the Family 62(4):1208-33.

Connell, Raewyn 2009. "Accountable Conduct: "Doing Gender" in Transsexual and Political Retrospect." Gender \& Society 23(1):104-11.

Cooke, Lynn Prince, and Janeen Baxter. 2010. "'Families' in International Context: Comparing Institutional Effects across Western Societies." Journal of Marriage and Family 72:516-36.

Crabb, Annabel. 2015. The Wife Drought. Sydney: Random House.

Craig, Lyn, and Michael Bittman. 2008. "The Effect of Children on Adults' Time-Use: An analysis of the incremental time costs of children in Australia." Feminist Economics 14(2):57-85.

Craig, Lyn, and Killian Mullan. 2010. "Parenthood, gender and work-family time in USA, Australia, Italy, France and Denmark " Journal of Marriage and Family 72(5):134461.

Craig, Lyn, Abigail Powell, and Judith Brown. 2015. " Co-resident parents and young people aged 15-34: who does what housework?" Social Indicators Research 121(2):569-88.

Crompton, Rosemary, Michaela Brockmann, and Clare Lyonette. 2005. "Attitudes, women's employment and the domestic division of labour: a cross-national analysis in two waves." Work, Employment and Society 19(2):213-33.

de Vaus, David. 2004. "Diversity and change in Australian families: Statistical profiles." Melbourne: Australian Institute of Family Studies.

Dempsey, Ken. 2001. "Women's and men's consciousness of shortcomings in marital relations, and of the need for change." Family Matters 58(Autumn):58-63.

Deutsch, Francine. 2000. Halving it All: How Equally Shared Parenting Works. Cambridge MA: Harvard University Press.

Dribe, Martin, and Maria Stanfors. 2009. "Does Parenthood Strengthen a Traditional Household Division of Labor? Evidence From Sweden." Journal of Marriage and Family 71(1):33 - 45. 
England, Paula. 2010. "The Gender Revolution: Uneven and Stalled " Gender \& Society 24(2):149-66.

—. 2011. "Reassessing the Uneven Gender Revolution and its Slowdown." Gender \& Society 25(1):113-23.

Fineman, Martha. 2004. The Autonomy Myth: A Theory of. Dependency. New York: The New Press.

Folbre, Nancy. 2001. The Invisible Heart: economics and family values. New York: The New Press.

Fuwa, Makiko. 2004. "Macro-level Gender Inequality and the Division of Household Labor in 22 Countries." American Sociological Review 69(6):751-67.

Geist, Claudia. 2005. "The Welfare State and the Home: Regime Differences in the Domestic Division of Labour." European Sociological Review 21(1):23-41.

Gornick, Janet, and Marcia Meyers. 2003. Families that Work: Policies for Reconciling Parenthood and Employment. New York: Russell Sage.

—. 2004. "Welfare regimes in relation to paid work and care." Pp. 45-68 in Changing Life Patterns in Western Industrial Societies, edited by Janet Z. Giele and Elke Holst. Amsterdam: Elsevier Science Press.

Greenstein, Theodore. 2000. "Economic Dependence, Gender and the Division of Labour in the Home." Journal of Marriage and the Family 62(2):322-35.

Hilbrecht, Margot, Juri Zuzanek, and RC Mannell. 2008. "Time Use, Time Pressure and Gendered Behavior in Early and Late Adolescence." Sex Roles 58:342-57.

Hook, Jennifer. 2006. "Care in context: Men's unpaid work in 20 countries, 1965-2003." American Sociological Review 71(4):639-60.

—. 2010. "Gender Inequality in the Welfare State: Sex Segregation in Housework, 19652003." American Journal of Sociology 115(5):1480-523.

Ironmonger, Duncan. 2004. "Bringing up Betty and Bobby: The Macro Time Dimensions of Investment in the Care and Nurture of Children." Pp. 93-110 in Family Time: The Social Organisation of Care, edited by Nancy Folbre and Michael Bittman. London: Routledge.

Kloep, M., and L.B. Hendry. 2010. "Letting go or holding on? Parents' perceptions of their relationships with their children during emerging adulthood." British Journal of Developmental Psychology 28(4):817-34.

Lachance-Grzela, M., and G. Bouchard. 2010. "Why do women do the lion's share of housework? A decade of research." Sex Roles 63:767-80. 
Mahaffy, Kimberly A. 2004. "Gender, Race, Class, and the Transition to Adulthood: A Critical Review of the Literature " Sociological Studies of Children and Youth 9:1547.

Mattingly, Marybeth, and Liana Sayer. 2006. "Under pressure: Gender differences in the relationship between free time and feeling rushed." Journal of Marriage and the Family 68(1):205-21.

McMahon, Anthony. 1999. Taking Care of Men: Sexual Politics in the Public Mind. Cambridge: Cambridge University Press.

Miller, Pavla. 2005. "Useful and Priceless Children in Contemporary Welfare States." Social Politics: International Studies in Gender State and Society 12(1):3-41.

Mitchell, Barbara. 2004. "Home, But Not Alone: Socio-Cultural and Economic Aspects of Canadian Young Adults Sharing Parental Households." Atlantis 28(2):115-25.

—. 2006. "The Boomerang Age from Childhood to Adulthood: Emergent Trends and Issues for Aging Families." Canadian Studies in Population 33(2):155-78.

Punch, Samantha 2001. "Household Division of Labour: Generation, Gender, Age, Birth Order and Sibling Composition." Work, Employment \& Society 15(4):803-23.

Ridgeway, Cecilia, and Shelley Correll. 2004. "Unpacking the gender system: A Theoretical Perspective on Gender Beliefs and Social Relations." Gender \& Society 18(4):510-31.

Russell, Graeme. 1987. "Problems in role-reversed families." Pp. 161-79 in Reassessing fatherhood: New observations on fathers and the modern family, edited by Charlie Lewis and Margaret O'Brien. Thousand Oaks, CA: Sage Publications, Inc.

Sayer, Liana. 2005. "Gender, Time and Inequality: Trends in Women's and Men's Paid Work, Unpaid Work and Free Time." Social Forces 84(1):285-303.

Sayer, Liana, Suzanne Bianchi, and John Robinson. 2004. "Are Parents Investing Less in Children? Trends in Mothers' and Fathers' time with Children." American Journal of Sociology 110(1):1-43.

Strazdins, Lyndall, and Dorothy Broom. 2004. "Acts of Love (and Work) Gender Imbalance in Emotional Work and Women's Psychological Distress." Journal of Family Issues 25:356-78.

Sullivan, Oriel. 1997. "Time Waits For No (Wo)Man: An Investigation Of The Gendered Experience Of Domestic Time." Sociology 31(2):221-39.

West, Candace, and Don Zimmerman. 2009. "Accounting for Doing Gender." Gender \& Society 23(1):112-22.

Wight, Vanessa, Joseph Price, Suzanne Bianchi, and Bijou Hunt. 2009. "The time use of teenagers " Social Science Research 38(4):792-809. 
Figure 1: Shares of routine and non-routine housework and shares of housework for household and for self by parents' employment configuration

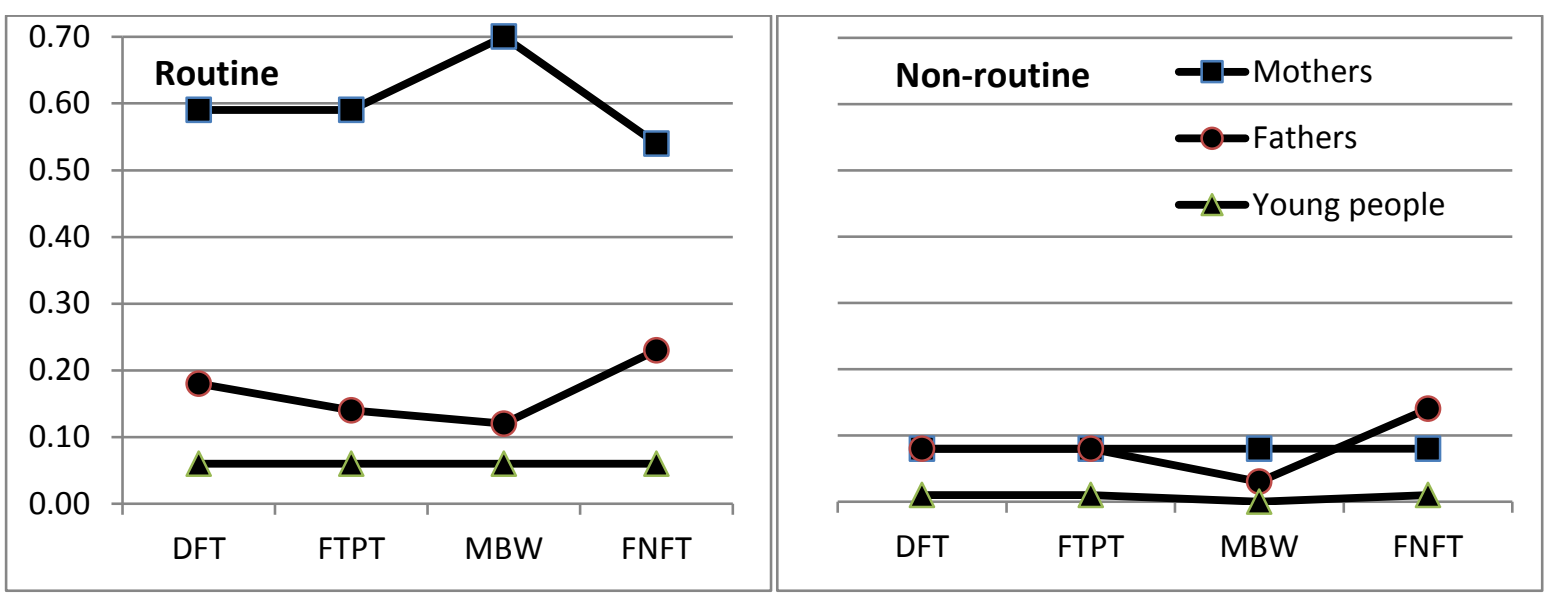

Shares of housework for household and for self by parents' employment configuration

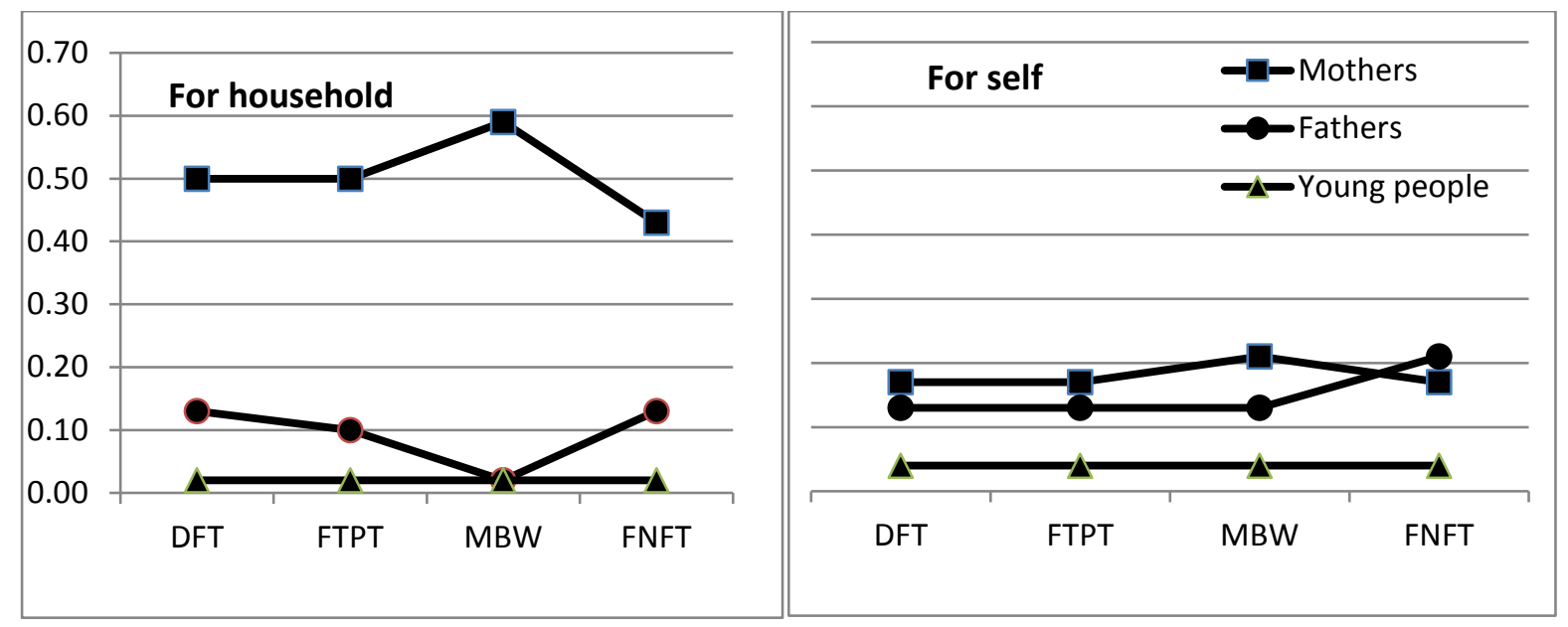

Key: DFT=dual full time, FTPT=fulltime/part time, MBW=male breadwinner, FNFT=father not full time 


\section{Table 1: Household characteristics}

\begin{tabular}{|c|c|c|}
\hline \multirow{4}{*}{$\begin{array}{l}\text { Parents' employment } \\
\text { status }\end{array}$} & Dual full-time earners (DFT) & $\begin{array}{l}32.5 \\
33.3\end{array}$ \\
\hline & Full-time employed father, part-time employed mother (FTPT) & \\
\hline & $\begin{array}{l}\text { Male breadwinner: full-time father, mother not employed } \\
\text { (MBW) }\end{array}$ & 12.9 \\
\hline & Other households - father not employed full-time (FNFT) & 21.3 \\
\hline No. of young people & 1 & 66.4 \\
\hline \multirow{2}{*}{$15-34$} & 2 & 28.7 \\
\hline & $3+$ & 4.9 \\
\hline \multirow{4}{*}{$\begin{array}{l}\text { Child(ren) under } 15 \text { in } \\
\text { household } \\
\text { Language spoken at } \\
\text { home }\end{array}$} & No & 69.5 \\
\hline & Yes & 30.5 \\
\hline & English & 87.7 \\
\hline & NESB & 12.3 \\
\hline \multirow{2}{*}{$\begin{array}{l}\text { Socio-economic } \\
\text { Indices For Area } \\
\text { (SES) }\end{array}$} & Lowest $60 \%$ & 53.2 \\
\hline & Highest $40 \%$ & 46.7 \\
\hline
\end{tabular}

Table 2: Mean shares of household labour by household member and type of domestic work

\begin{tabular}{lccccccc}
\hline Household labour... & ...which is routine & \multicolumn{4}{c}{...which is non-routine } \\
\hline & Mothers & Fathers & $\begin{array}{l}\text { Young } \\
\text { people }\end{array}$ & Mothers & Fathers & $\begin{array}{l}\text { Young } \\
\text { people }\end{array}$ & Total \\
\hline $\begin{array}{l}\text { Share } \\
\begin{array}{l}\text { Amount (mins a } \\
\text { day) }\end{array}\end{array}$ & 0.51 & 0.15 & 0.11 & 0.09 & 0.11 & 0.03 & 1.00 \\
\hline Household labour... & ...performed for the household & ...performed for oneself & \\
\hline $\begin{array}{l}\text { Share } \\
\begin{array}{l}\text { Amount (mins a } \\
\text { day) }\end{array}\end{array}$ & 0.44 & 0.16 & 0.05 & 0.16 & 0.10 & 0.09 & 1.00 \\
& 161 & 63 & 20 & 58 & 40 & 32 & 374 \\
\hline
\end{tabular}


Table 3: Estimates of mothers', fathers' and young people's shares of total household routine and non-routine domestic work

\begin{tabular}{|c|c|c|c|c|c|c|c|}
\hline & & \multicolumn{3}{|c|}{ Routine domestic work } & \multicolumn{3}{|c|}{ Non-routine domestic work } \\
\hline & & Mothers & Fathers & $\begin{array}{l}\text { Young } \\
\text { people }\end{array}$ & Mothers & Fathers & $\begin{array}{l}\text { Young } \\
\text { people }\end{array}$ \\
\hline \multicolumn{2}{|c|}{ Intercept (note: row sums to 1 ) } & $\begin{array}{l}0.57 * * * \\
(0.05)\end{array}$ & $\begin{array}{l}0.17 * * * \\
(0.03)\end{array}$ & $\begin{array}{l}0.08 * * \\
(0.03)\end{array}$ & $\begin{array}{l}0.09 * * * \\
(0.02)\end{array}$ & $\begin{array}{l}0.08 * * \\
(0.03)\end{array}$ & $\begin{array}{l}0.01 \\
(0.02)\end{array}$ \\
\hline \multirow{6}{*}{$\begin{array}{l}\text { Parents' employment } \\
\text { status }\end{array}$} & Dual full-time earner & & & & & & \\
\hline & Full-time male, part-time female & $\begin{array}{l}0.03 \\
(0.03)\end{array}$ & $\begin{array}{l}-0.04 * \\
(0.02)\end{array}$ & $\begin{array}{l}-0.01 \\
(0.02)\end{array}$ & $\begin{array}{l}0.02 \\
(0.01)\end{array}$ & $\begin{array}{l}0.00 \\
(0.01)\end{array}$ & $\begin{array}{l}0.00 \\
(0.01)\end{array}$ \\
\hline & Male breadwinner & $0.13 * *$ & $-0.08 * * *$ & -0.01 & 0.02 & $-0.06 * * *$ & -0.02 \\
\hline & & $(0.03)$ & $(0.02)$ & $(0.02)$ & $(0.01)$ & $(0.02)$ & $(0.01)$ \\
\hline & Father not full-time & -0.04 & 0.03 & -0.03 & -0.02 & $0.05 * *$ & -0.01 \\
\hline & & $(0.03)$ & $(0.03)$ & $(0.02)$ & $(0.01)$ & $(0.02)$ & $(0.01)$ \\
\hline \multirow{2}{*}{\multicolumn{2}{|c|}{ No of young people 15-34 in household }} & 0.00 & -0.01 & $0.05 * * *$ & $-0.02 * *$ & $-0.03 * *$ & $0.01^{*}$ \\
\hline & & $(0.02)$ & $(0.01)$ & $(0.01)$ & $(0.01)$ & $(0.01)$ & $(0.00)$ \\
\hline \multirow{2}{*}{\multicolumn{2}{|c|}{ Child(ren) aged 0-14 in household }} & 0.02 & 0.01 & 0.00 & $-0.03 * *$ & -0.01 & 0.00 \\
\hline & & $(0.03)$ & $(0.02)$ & $(0.02)$ & $(0.01)$ & $(0.01)$ & $(0.01)$ \\
\hline \multirow{2}{*}{\multicolumn{2}{|c|}{ Non-English-speaking household }} & $0.10 * *$ & $-0.04^{* *}$ & -0.01 & -0.01 & -0.02 & $-0.01^{x}$ \\
\hline & & $(0.03)$ & $(0.02)$ & $(0.02)$ & $(0.01)$ & $(0.02)$ & $(0.01)$ \\
\hline Socio-Economic & Lowest $60 \%$ & & & & & & \\
\hline \multirow[t]{2}{*}{ Status (SES) } & Highest $40 \%$ & -0.02 & 0.02 & 0.00 & 0.00 & -0.00 & -0.01 \\
\hline & & $(0.02)$ & $(0.02)$ & $(0.01)$ & $(0.01)$ & $(0.01)$ & $(0.01)$ \\
\hline \multirow{2}{*}{\multicolumn{2}{|c|}{ Total domestic work }} & $-0.00 * * *$ & $-0.00 * *$ & $-0.00 * * *$ & $0.00 * *$ & $0.00 * * *$ & $0.00 *$ \\
\hline & & $(0.00)$ & $(0.00)$ & $(0.00)$ & $(0.00)$ & $(0.00)$ & $(0.00)$ \\
\hline \multicolumn{2}{|l|}{$\mathrm{R}$ squared } & 0.07 & 0.06 & 0.06 & 0.12 & 0.14 & 0.03 \\
\hline
\end{tabular}


Table 4: Estimates of mothers', fathers' and young people's shares of total household domestic work by 'for whom' activity is done

\begin{tabular}{|c|c|c|c|c|c|c|c|}
\hline & & \multicolumn{3}{|c|}{ For household } & \multicolumn{3}{|c|}{ For self only } \\
\hline & & Mothers & Fathers & $\begin{array}{l}\text { Young } \\
\text { people }\end{array}$ & Mothers & Fathers & $\begin{array}{l}\text { Young } \\
\text { people }\end{array}$ \\
\hline \multicolumn{2}{|c|}{ Intercept (note: row sums to 1 ) } & $\begin{array}{l}0.47 * * * \\
(0.05)\end{array}$ & $\begin{array}{l}0.12 * * \\
(0.04)\end{array}$ & $\begin{array}{l}0.03 \\
(0.02)\end{array}$ & $\begin{array}{l}0.18 * * * \\
(0.04)\end{array}$ & $\begin{array}{l}0.14 * * * \\
(0.03)\end{array}$ & $\begin{array}{l}0.06 * * \\
(0.03)\end{array}$ \\
\hline \multirow{4}{*}{$\begin{array}{l}\text { Parents' employment } \\
\text { status }\end{array}$} & Dual full-time & & & & & & \\
\hline & Full-time male, part-time female & $\begin{array}{l}0.01 \\
(0.03)\end{array}$ & $\begin{array}{l}-0.03 \\
(0.02)\end{array}$ & $\begin{array}{l}0.00 \\
(0.01)\end{array}$ & $\begin{array}{l}0.03 \\
(0.02)\end{array}$ & $\begin{array}{l}-0.01 \\
(0.01)\end{array}$ & $\begin{array}{l}-0.00 \\
(0.01)\end{array}$ \\
\hline & Male breadwinner & $\begin{array}{l}0.11 * * \\
(0.04)\end{array}$ & $\begin{array}{l}-0.12 * * * \\
(0.02)\end{array}$ & $\begin{array}{l}-0.01 \\
(0.01)\end{array}$ & $\begin{array}{l}0.05^{\mathrm{X}} \\
(0.03)\end{array}$ & $\begin{array}{l}0.00 \\
(0.02)\end{array}$ & $\begin{array}{l}-0.02 \\
(0.01)\end{array}$ \\
\hline & Father not full-time & $\begin{array}{l}-0.07 \\
(0.04)\end{array}$ & $\begin{array}{l}0.03 \\
(0.02)\end{array}$ & $\begin{array}{l}-0.02 \\
(0.01)\end{array}$ & $\begin{array}{l}0.01 \\
(0.03)\end{array}$ & $\begin{array}{l}0.07 * * \\
(0.02)\end{array}$ & $\begin{array}{l}-0.02 \\
(0.01)\end{array}$ \\
\hline \multicolumn{2}{|c|}{ No of young people $15-34$ in household } & $\begin{array}{l}-0.02 \\
(0.02)\end{array}$ & $\begin{array}{l}-0.01 \\
(0.01)\end{array}$ & $\begin{array}{l}0.02 * * \\
(0.01)\end{array}$ & $\begin{array}{l}-0.01 \\
(0.02)\end{array}$ & $\begin{array}{l}-0.03 * * \\
(0.01)\end{array}$ & $\begin{array}{l}0.05 * * * \\
(0.01)\end{array}$ \\
\hline \multicolumn{2}{|c|}{ Child(ren) aged 0-14 in household } & $\begin{array}{l}0.05^{\mathrm{X}} \\
(0.03)\end{array}$ & $\begin{array}{l}0.04^{*} \\
(0.02)\end{array}$ & $\begin{array}{l}0.00 \\
(0.01)\end{array}$ & $\begin{array}{l}-0.04 * * \\
(0.02)\end{array}$ & $\begin{array}{l}-0.04 * * \\
(0.01)\end{array}$ & $\begin{array}{l}0.00 \\
(0.01)\end{array}$ \\
\hline \multicolumn{2}{|c|}{ Non-English-speaking household } & $\begin{array}{l}0.05 \\
(0.04)\end{array}$ & $\begin{array}{l}-0.04^{X} \\
(0.02)\end{array}$ & $\begin{array}{l}0.00 \\
(0.01)\end{array}$ & $\begin{array}{l}0.04 \\
(0.04)\end{array}$ & $\begin{array}{l}-0.02 \\
(0.02)\end{array}$ & $\begin{array}{l}-0.02 \\
(0.01)\end{array}$ \\
\hline \multirow{2}{*}{$\begin{array}{l}\text { Socio-Economic Status } \\
\text { (SES) }\end{array}$} & Lowest 60\% & & & & & & \\
\hline & Highest $40 \%$ & $\begin{array}{l}-0.02 \\
(0.02)\end{array}$ & $\begin{array}{l}0.02 \\
(0.02)\end{array}$ & $\begin{array}{l}-0.01 \\
(0.01)\end{array}$ & $\begin{array}{l}0.01 \\
(0.02)\end{array}$ & $\begin{array}{l}0.00 \\
(0.01)\end{array}$ & $\begin{array}{l}0.00 \\
(0.01)\end{array}$ \\
\hline \multicolumn{2}{|l|}{ Total domestic work } & $\begin{array}{l}-0.00 \\
(0.00)\end{array}$ & $\begin{array}{l}0.00 * * \\
(0.00)\end{array}$ & $\begin{array}{l}0.00 \\
(0.00)\end{array}$ & $\begin{array}{l}0.00 \\
(0.00)\end{array}$ & $\begin{array}{l}0.00 \\
(0.00)\end{array}$ & $\begin{array}{l}-0.00 * * \\
(0.00)\end{array}$ \\
\hline \multicolumn{2}{|l|}{ R squared } & 0.04 & 0.07 & 0.04 & 0.02 & 0.07 & 0.05 \\
\hline
\end{tabular}

$\mathrm{p}<0.10^{\mathrm{X}}, * \mathrm{p}<0.05, * * \mathrm{p}<0.01, * * * \mathrm{p}<0.001$, standard errors in parenthesis 